\title{
Determinants of Trade Flows between Colombia and South Korea
}

\author{
Sandra Daniela Ariza Marin*
}

Date of reception: April 9 of 2020

Date of acceptance: June 23 of 2020

\begin{abstract}
This paper identifies the determinants of trade flows between Colombia and South Korea. For this purpose, the economic and commercial profile for both countries, bilateral trade and the signed FTA were analyzed. Likewise, a gravity model for total and sectorial trade with panel data for the period of 1993-2013 is applied, finding consistencies with the theoretical postulates. Variables such as income of the importer and exporter countries determine positive and significant bilateral trade, while the distance and landlocked decrease the likelihood of trade. Furthermore, the results of the gravity model indicate that the free trade agreements have no significant impact on trade of South Korea; however, from the analysis of the agreement it is considered that Colombian agricultural and agro-industrial products have potential opportunities to compete in the Asian country.
\end{abstract}

Keywords: bilateral trade; gravity model; free trade agreement; Colombia; South Korea.

Clasificación JEL: F14, F15.

Cómo citar este artículo/ To reference this article / Comment citer cet article / Para citar este artigo:

Ariza Marin, S. D. (2020). Determinants of Trade Flows between Colombia and South Korea. Apuntes Del Cenes, 39(70). Págs. 75 - 105. https://doi.org/10.19053/01203053.v39.n70.2020.10840

\footnotetext{
* Master in Economics. Professor and researcher in Universidad Libre (Pereira), Colombia. E-mail:sandrad.arizam@ unilibre.edu.co (iD http://orcid.org/0000-0002-9710-5997
} 


\section{Determinantes de los flujos comerciales entre Colombia y Corea del Sur}

\section{Resumen}

Este trabajo de investigación identifica los determinantes de los flujos comerciales entre Colombia y Corea del Sur. Para ello, se analiza el perfil comercial de ambos países, el comercio bilateral y el TLC firmado. Así mismo, se aplica un modelo gravitacional para el comercio total y sectorial con datos de panel para el período 1993-2013, encontrando consistencia con los postulados teóricos. De manera que variables como los ingresos de los países importadores y exportadores determinan el comercio bilateral positivo y significativo, mientras que la distancia y el litoral disminuyen la probabilidad de comercio. Además, los resultados del modelo gravitacional indican que los acuerdos de libre comercio no tienen un efecto significativo en el comercio de Corea del Sur de acuerdo con la estimación realizada; sin embargo, del análisis del acuerdo se considera que los productos agrícolas y agroindustriales colombianos tienen oportunidades potenciales para competir en el país asiático.

Palabras clave: Comercio bilateral; modelo gravitacional; tratado de libre comercio; Corea del Sur; Colombia. 


\section{INTRODUCTION}

The Colombian government has a growing interest in strengthening trade relations with Asian countries with the purpose of attracting productive foreign investment and obtaining preferential access for merchants of goods and services in different markets. Accordingly, Colombia is part of the Pacific Alliance ${ }^{1}$ since 2012 and signed the Free Trade Agreement (FTA) with the Republic of Korea ${ }^{2}$ in 2013.

The FTA between Colombia and South Korea implies preferential access to a population of 50 million people with a high gross domestic product (GDP) per capita, as well as a broad elimination of tariffs to boost bilateral exchanges and investments. According to the Ministry of Commerce, Industry and Tourism (MinCIT, 2013a), the agreement has multiple advantages for both consumers and employers. For consumers, because they will have access to more goods with better prices, and for entre- preneurs, because they will have new opportunities to export as it is expected that companies from all sectors benefit from the progressive elimination of tariffs for raw materials, inputs and intermediate goods.

Regarding the government's objective of deepening the insertion of Colombia in the Asian region and the entry into force of the FTA with South Korea in 2016, it is considered important to validate whether the total and sectoral trade volume between the two countries is determined by economic, geographical, cultural and commercial variables. From the above, the hypothesis proposed is: the bilateral trade flows between South Korea and Colombia are determined by economic, geographic, commercial and cultural variables. In this sense, the gravity model $(\mathrm{GM})^{3}$ with data for the period 1993-2013 is used, among the reasons that justify the use of this model is that it allows to include potential supply factors (GDP of the exporter), potential demand (GDP of the importer), among

1 Initiative of regional integration comprised by Chile, Colombia, Mexico and Peru, officially established on April 28th, 2011.

2 Usually known as South Korea.

3 In the document, gravity equation (EG) and gravity model (MG) are used interchangeably. 
other variables that stimulate or hinder commercial exchange such as distance, language, and the entry into force of the commercial agreement.

Likewise, due to the entry into force of the FTA, the investigation includes the relevant negotiated aspects and identifies possible opportunities for Colombian products with comparative advantage; however, a robust analysis of the general and sectoral impacts of the agreement is not carried out, trade in services and bilateral investment are not analyzed, and the development policies of each country that influenced the commercial and economic dynamics are not studied in detail.

The article is organized as follows. This introduction as section one. Section two presents the main theoretical and empirical postulates that explain the determinants of international trade. Section three describes the commercial profile of Colombia and South Korea as well as the behavior of bilateral trade. Section four exposes the aspects negotiated in the FTA in order to identify possible implications for Colombia's foreign trade. Section five establishes the determinants of South Korean trade flows through the gravity model. Finally, the conclusions are presented.

\section{LITERATURE REVIEW: WHAT DETERMINES INTERNATIONAL TRADE?}

The discussion about the causes of international trade arouses various theories and techniques of empirical approximation for its study. Three theoretical reasons are generally accepted. First of all, countries trade because they are different and can benefit from a relationship in which everyone does what they know how to do relatively well. Secondly, countries trade to achieve economies of scale in production. Finally, it points out heterogeneous companies as a source of trade.

Ricardo's model ${ }^{4}$ shows that when an economy can produce a good with a lower opportunity cost in terms of other goods than a given country, it has a comparative advantage in the production of this good. And the Heckscher-Ohlin model ${ }^{5}$ states that factor endowments are the main determinants of comparative advantage and therefore of international trade. Hence, a country must specialize in the production and export of the good whose production requires a greater quantity of the relatively more abundant production factor, and import the good whose production is intensive in the scarcest factor (Krugman \& Obstfeld, 2005).

4 As found in the book The Principles of Political Economy and Taxation, published in 1817

5 Formulated by the economist Bertil Ohlin in 1933, modifying the initial theorem of Eli Heckscher, formulated in 1919. 
The Ricardian and Heckscher-Ohlin models present as a trade determinant the comparative advantage based on differences among nations, giving rise to inter-industrial trade; in other words, the exchange of products of different industries. However, the current panorama shows the growing importance of the exchange of differentiated products within the same industry, called intra-industrial trade, between economies with similar factor endowments or levels of development.

The trade of differentiated products within the same industry arises mainly from economies of scale (or increasing returns), which make it advantageous for each country to specialize in the production of a limited range of goods that are produced on a larger scale and, therefore, more efficiently than trying to produce everything (Krugman, 1980).

The relative importance of inter-industrial and intra-industrial trade depends on the similarity among countries. On the one hand, if countries have different factor endowments, the flow of inter-industrial trade based on comparative advantage is greater; on the other hand, if factor endowments are similar, intra-industrial trade based on economies of scale is greater (Krugman, 1981, 1983).
Finally, in the 1980s, special attention was given to the heterogeneous productivity of companies as an important driver of trade flows. The so-called sunk costs (or irreversible costs) incurred by firms to enter or leave the export markets and that make them react to shocks in the exchange rate, are fundamental in exporting and non-exporting companies to make decisions (Dixit, 1989; Melitz, 2003).

Melitz (2003) points out that exposure to trade induces the most productive firms to export, while less productive firms will produce only in the domestic market or will exit the market. This reallocation of companies into economic activity increases aggregate productivity and provides a non-traditional source of trade welfare.

In relation to the techniques of empirical approximation to study trade flows, the gravity model of trade is one of the most used tools to contrast some theories of international trade and determine the effect on exports and imports of economic variables, geographical, among others. "The gravity model states that bilateral trade flows between two countries, like the gravity concept in physics, are driven by forces which either impede or accelerate these flows" (Anaman \& Al-Kharusi, 2003, p. 63).

\footnotetext{
$6 \quad$ Newton's Law of Gravitation argues that the force of attraction between two bodies is directly proportional to their respective masses and inversely proportional to the square of the distance that separates them. The relationship is given by $F G=G \frac{M_{1} M_{2}}{\left(\text { Dist }_{12}\right)^{2}}$
} 
Hellvin \& Nilsson claim that bilateral trade is determined by "three sets of variables: i) variables indicating total potential demand of the importing country i, ii) variables indicating total potential supply of the exporting country $\mathrm{j}$, and (iii) variables aiding or hindering trade between importing and exporting countries" $(2000$, p.6). In the first and second sets there are variables related to the size of the economies of the importer and exporter (approximated by GDP or population), respectively; and in the third set there are variables such as transportation costs, culture, trade agreements, among other factors.

Tinbergen (1962) pioneered the use of the gravity model, since it is used to study trade flows among countries; however, the model was not widely accepted by the perception that it was more an analogy with physics than an analysis economic. Given its success as an empirical tool, a series of research studies have shown that the gravity equation fits different international trade models.

Deardorff (1998) constructed an equation theoretically consistent with the Hecksher-Ohlin model of interindustry trade. Likewise, Bergstrand (1985), Helpman \& Krugman (1985) found a version of the equation starting from the assumptions of product differentiation and economies of scale. While Bergstrand (1989), Evenett and Keller
(2002) derive the equation from the Hecksher-Ohlin theory and the increasing returns theory, concluding that factor endowments and economies of scale explain different components of production patterns and trade volumes.

Furthermore, Helpman et al. (2008) found this empirical tool also compatible with the new theory of international trade. This compatibility was exposed with a model of heterogeneous companies where they present evidence in favor of a process of selecting the most productive firms in export markets.

From the fact that the equation can be derived from various theories of international trade, the idea that the gravity equation arose from a simple analogy with physics was disappearing. However, Anderson \& Van Wincoop pointed out that the estimate still suffered bias from variables omitted due to the lack of theoretical support; therefore, they develop a specification that includes the term multilateral trade resistance, it means, "the more resistance there is to trade with other regions, the more it is pushed to trade with a given bilateral partner" (2003, p. 170). Hence, in this research the gravity model of Anderson \& Van Wincoop (2003) is used to evaluate whether variables such as GDP, the distance, the language, the absence of coast, and the trade agreements determine the commercial flows of South Korea. 
Different studies analyze bilateral trade between Colombia and South Korea. The MinCIT (2010) identified some competitive products measured through the Relative Trade Balance Index, highlighting opportunities for products from the mining sector (bronze and ferronickel) and the agricultural sector (coffee, potatoes, panela, flowers, palm oil). In addition, the study concludes that due to the growing commercial dynamic and purchasing capacity of the Asian country it is feasible to consider it as a partner. On the other hand, Reina et al. (2009) identified Colombian sectors with export and import potential. The study concludes that businessmen find logistics, transportation, and high national tariffs as obstacles to bilateral trade with South Korea.

The studies described are limited to analyzing the possible opportunities of Colombian products in South Korea, and the advantages for the Colombian economy when the agreement enters into force on the basis of descriptive analysis and commercial indicators. Therefore, in this research the gravity model of Anderson \& Van Wincoop (2003) is used to evaluate whether variables such as GDP, the distance, the language, the absence of coast and the trade agreements determine the commercial flows of South Korea and, thus, to identify if there are possibilities of increasing trade with the Asian country.

\section{COMMERCIAL PROFILES OF COLOMBIA AND SOUTH KOREA ${ }^{7}$}

The trade profiles of Colombia and South Korea show important differences, among which stand out the behavior of flows in recent decades, the balance of the trade balance, and the trade partners. The average annual growth of Colombian exports in the period 19602013 was $4.9 \%$, while imports increased to $6.2 \%$, which implies a growing deficit in the trade balance in the period studied. The main export destinations of Colombia this year were: United States $(40.0 \%)$, China $(8.7 \%)$ and Panama $(5.5 \%)$, while $59 \%$ of imports come from countries in the Americas as The United States (27.7\%), Mexico (9.3\%) and Brazil (4.4\%), and China (17.5\%).

South Korea imported more than it exported in the 1960s, although a change in trade policy towards a focus on exports generated a significant growth in foreign sales, generating a surplus trade balance in the 1980s and in the present day. South Korea's exports and imports grew at a rate of $16.0 \%$ and $11.8 \%$, respectively. Its main trading partners were Asian countries, including China, Japan, Hong Kong (China), Singapore and Qatar. However, the United States is also an important partner. \begin{tabular}{l}
\hline $\begin{array}{l}\text { The data used in this section was obtained from the databases: World Integrated Trade Solution (WITS) } \\
\text { and Comtrade. }\end{array}$
\end{tabular} 


\section{Export and import products}

Exports and imports of Colombia and South Korea are presented, according to the group of products to which that belongs, taking into account the determinants of trade may vary according to the type of commercialized products ${ }^{8}$.

The sectoral importance of Colombian exports changed from 1993 to 2013. In 1993, fuels accounted for $26.5 \%$ of foreign sales, but recently it became the main export product, accounting for $66.8 \%$ in 2013. In contrast, vegetable products and textiles, that corresponded to $28.3 \%$ and $10.4 \%$ of exports when the 90's opening process began, it represented $7.6 \%$ and $1.7 \%$ in 2013 , respectively. On the other hand, Colombian imports have less concentration and its sectoral participation is similar in 1993 and 2013. The main import groups were machinery and electricity (23.4\%), chemical products $(14.0 \%)$ and transport (13.7\%) in 2013.

Table 1. Colombia: Exports and Imports, 1993 y 2013

\begin{tabular}{ccccccccc}
\hline \multirow{2}{*}{ Product Groups } & \multicolumn{9}{c}{ Exports } \\
\cline { 2 - 10 } & $\mathbf{1 9 9 3}$ & $\mathbf{( \% )}$ & $\mathbf{2 0 1 3}$ & $\mathbf{( \% )}$ & $\mathbf{1 9 9 3}$ & $\mathbf{( \% )}$ & $\mathbf{2 0 1 3}$ & $\mathbf{( \% )}$ \\
\hline Animal & 165.048 & 2,3 & 702.105 & 1,2 & 60.041 & 0,6 & 497.993 & 0,8 \\
Vegetable & 2.013 .591 & 28,3 & 4.468 .333 & 7,6 & 520.954 & 5,3 & 3.221 .873 & 5,4 \\
Food Products & 352.158 & 4,9 & 1.414 .536 & 2,4 & 205.320 & 2,1 & 2.353 .658 & 4,0 \\
Minerals & 47.905 & 0,7 & 36.718 & 0,1 & 65.003 & 0,7 & 218.922 & 0,4 \\
Fuels & 1.887 .921 & 26,5 & 39.278 .441 & 66,8 & 371.908 & 3,8 & 6.388 .883 & 10,8 \\
Chemicals & 246.848 & 3,5 & 2.347 .629 & 4,0 & 1.404 .438 & 14,3 & 8.287 .737 & 14,0 \\
Plastic or Ruber & 230.779 & 3,2 & 1.719 .306 & 2,9 & 476.669 & 4,9 & 3.587 .722 & 6,0 \\
Hides and Skins & 165.853 & 2,3 & 283.798 & 0,5 & 45.334 & 0,5 & 202.241 & 0,3 \\
Wood & 212.667 & 3,0 & 704.866 & 1,2 & 329.710 & 3,4 & 1.247 .961 & 2,1 \\
Textiles and & 743.762 & 10,4 & 995.522 & 1,7 & 430.195 & 4,4 & 2.318 .302 & 3,9 \\
Clothing & 101.510 & 1,4 & 55.391 & 0,1 & 17.058 & 0,2 & 559.976 & 0,9 \\
Footwear & 502.051 & 7,1 & 2.911 .557 & 5,0 & 106.866 & 1,1 & 759.675 & 1,3 \\
Stone and Glass & 192.082 & 2,7 & 1.705 .091 & 2,9 & 853.157 & 8,7 & 4.251 .134 & 7,2 \\
Metals & 156.551 & 2,2 & 960.125 & 1,6 & 2.377 .021 & 24,2 & 13.899 .175 & 23,4 \\
Mach and Elec & 40.218 & 0,6 & 882.872 & 1,5 & 1.511 .011 & 15,4 & 8.114 .333 & 13,7 \\
Transportation & 64.494 & 0,9 & 355.578 & 0,6 & 1.054 .474 & 10,7 & 3.471 .613 & 5,9 \\
Miscellanous & 7.123 .439 & 100,0 & 58.821 .870 & 100,0 & 9.829 .161 & 100,0 & 59.381 .197 & 100,0 \\
Total & & & & & & &
\end{tabular}

Source: Author elaboration based on WITS

The five main export products (to six digits) represented $71.8 \%$ in 2013, highlighting crude petroleum oils and oils obtained from bituminous minerals
(47.0\%) and bituminous coal, not agglomerated (7.4\%). This demonstrates the high concentration of Colombian export basket and dependence on external fuel

$8 \quad$ The analysis is based on the product groups conformed by chapters (two digits) of the Harmonized System (HS) (See Appendix 1). 
sales, which the high impact of changes in the price of this commodity in the national economy and particularly in the trade balance is derived, while the product (to six digits) that has greater participation in imports is petroleum oils or bituminous minerals (excl. crude) $(10.7 \%)$, and of the group of machinery and electricity, transmission apparatus $(2.9 \%)$ and digital auto data-processing machines (2.3\%) stands out. (See Appendix 2).

Regarding South Korea, it was identified that in 2013, exports of products related to machinery and electricity (34.6\%), transportation (19.8\%) and fuels $(9.7 \%)$ predominated. The external sales of fuel were four times the amount compared to 1993, while there was a decrease in the participation of textiles and clothing.

Around $50 \%$ of the imports from the Asian country correspond to fuels $(35.0 \%)$ and machinery and electricity (22.4\%), highlighting the increase in the share of fuels and the decrease in products such as machinery and electricity, metals and chemical products. And, four out of the five products (to six digits) with the highest imported value are fuels, highlighting crude petroleum oils and oils obtained from bituminous minerals (19.3\%). (See Appendix 3).

Table 2. South Korea: Exports and Imports, 1993 y 2013

\begin{tabular}{ccccccccc}
\hline Product & \multicolumn{3}{c}{ Exports } \\
\cline { 2 - 9 } Groups & $\mathbf{1 9 9 3}$ & $\mathbf{( \% )}$ & $\mathbf{2 0 1 3}$ & $\mathbf{( \% )}$ & $\mathbf{1 9 9 3}$ & $\mathbf{( \% )}$ & $\mathbf{2 0 1 3}$ & $\mathbf{( \% )}$ \\
\hline Animal & 1.100 .651 & 1,3 & 1.904 .395 & 0,3 & 1.057 .917 & 1,3 & 6.989 .226 & 1,4 \\
Vegetable & 467.413 & 0,6 & 934.706 & 0,2 & 2.541 .695 & 3,0 & 11.210 .383 & 2,2 \\
Food Products & 875.350 & 1,1 & 4.118 .167 & 0,7 & 1.600 .157 & 1,9 & 8.386 .192 & 1,6 \\
Minerals & 287.878 & 0,4 & 674.091 & 0,1 & 1.906 .030 & 2,3 & 17.501 .079 & 3,4 \\
Fuels & 1.851 .735 & 2,3 & 54.112 .787 & 9,7 & 15.052 .769 & 18,0 & 180.432 .793 & 35,0 \\
Chemicals & 2.724 .586 & 3,3 & 38.380 .207 & 6,9 & 7.200 .829 & 8,6 & 38.723 .908 & 7,5 \\
Plastic or Ruber & 4.173 .908 & 5,1 & 39.527 .457 & 7,1 & 2.389 .728 & 2,9 & 13.711 .078 & 2,7 \\
Hides and Skins & 2.845 .596 & 3,5 & 1.679 .737 & 0,3 & 1.707 .323 & 2,0 & 3.345 .293 & 0,7 \\
Wood & 805.076 & 1,0 & 3.919 .658 & 0,7 & 4.115 .291 & 4,9 & 6.908 .240 & 1,3 \\
Textiles and & 14.508 .328 & 17,6 & 15.727 .166 & 2,8 & 4.011 .138 & 4,8 & 13.239 .978 & 2,6 \\
Clothing & & & & & & & \\
Footwear & 2.576 .831 & 3,1 & 711.699 & 0,1 & 184.173 & 0,2 & 2.284 .966 & 0,4 \\
Stone and Glass & 1.123 .684 & 1,4 & 6.018 .613 & 1,1 & 1.387 .019 & 1,7 & 9.612 .781 & 1,9 \\
Metals & 8.211 .516 & 10,0 & 46.057 .440 & 8,2 & 7.462 .815 & 8,9 & 45.508 .512 & 8,8 \\
Mach and Elec & 27.589 .427 & 33,6 & 193.402 .835 & 34,6 & 24.661 .216 & 29,4 & 115.328 .264 & 22,4 \\
Transportation & 10.142 .576 & 12,3 & 110.868 .361 & 19,8 & 3.825 .744 & 4,6 & 15.425 .562 & 3,0 \\
Miscellanous & 2.947 .561 & 3,6 & 41.581 .238 & 7,4 & 4.690 .120 & 5,6 & 26.964 .717 & 5,2 \\
Total & 82.232 .116 & 100 & 559.618 .559 & 100 & 83.793 .964 & 100 & 515.572 .970 & 100 \\
\hline
\end{tabular}

Source: Author elaboration based on WITS 
Bilateral Trade between Colombia and South Korea

In the 1993-2013 period, bilateral trade flows grew, exports and imports increased at an average annual rate of
$7.1 \%$ and $7.6 \%$, respectively (Figure 1). Colombian exports to the Asian country are lower than imports originating in South Korea; this implies a deficit trade balance for Colombia.

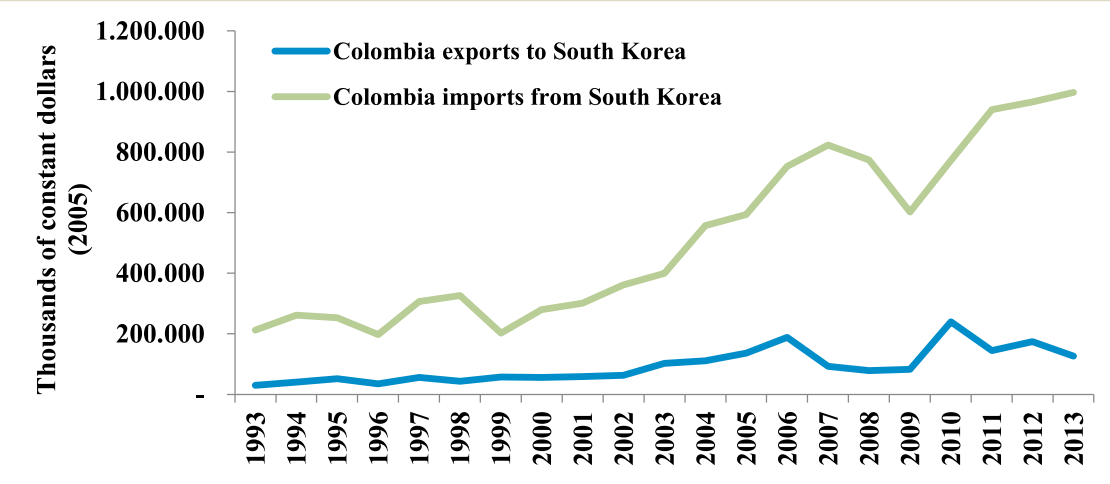

Figure 1. Bilateral Trade between Colombia and South Korea.

Source: Author elaboration based on WITS

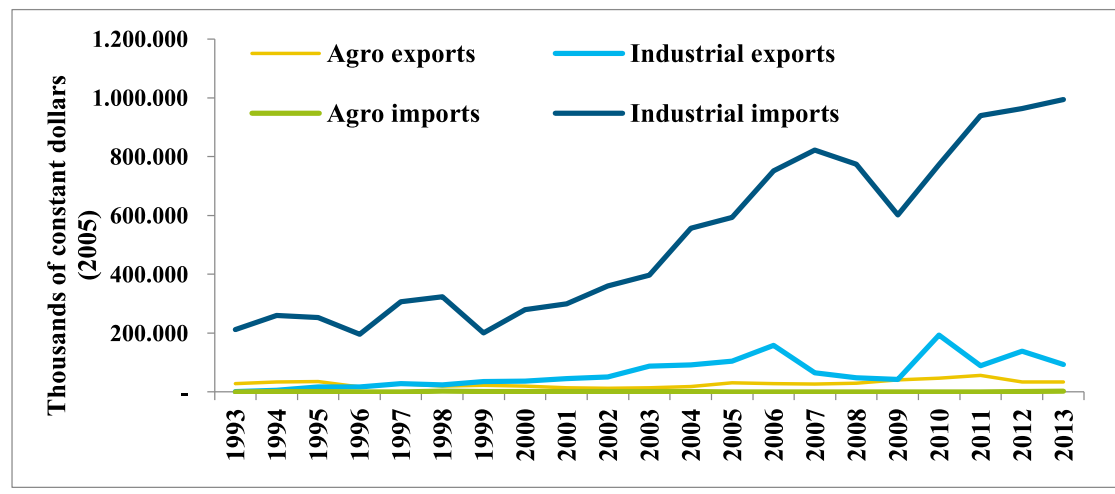

Figure 2. Sectoral Exports and Imports of Colombia to and from South Korea.

Source: Author elaboration based on WITS

Nonetheless, the trade ratio between countries is marginal, only $0.4 \%$ of Colombian exports went to South Korea in 2013 , and $2.2 \%$ of the imports came from the Asian country. This scenario does not differ from the perspective of South Korea, where exports to Colombia 
represent $0.2 \%$ of its total sales and imports represent $0.04 \%$ of its purchases to the foreign market ${ }^{9}$.

The trade between Colombia and South Korea is inter-industrial (Figure 2), the balance is surplus for Colombia in the primary products (agricultural and agro-industrial), but have a trade balance deficit in the secondary products (industrial) ${ }^{10}$.

When studying the products traded by chapters of the Harmonized System (to two digits), it was found that $78.3 \%$ of Colombian exports to South Korea corresponded to coffee, tea, mate and spices in 1993. Coffee remained the most exported agricultural product $(13.5 \%)$, but iron and steel accounted for $79.7 \%$ of sales in 2003. And in 2013, coffee exports and related products increased (20.7\%), exports of iron and steel decreased (25.8\%), but mineral fuels and mineral oils (31.4\%) began to play an important role of the Colombian export basket to the Asian country (See Appendix 4). Regarding Colombia imports from South Korea, in 2013 predominated products related to machinery and electricity $(20.9 \%)$ and transport (41.5\%) groups (See Appendix 5).

\section{Revealed Comparative Advantage (RCA) Index}

The analysis of sectoral competitiveness in bilateral trade is based on Balassa's Revealed Comparative Advantage Index for the Harmonized System (HS) product groups. The RCA Index or degree of specialization $(\mathrm{GE})^{11}$ is expressed as:

$$
G E_{i}=\frac{\left(M_{i j}-M_{n j}\right)}{\left(M_{i t}+M_{n t}\right)}
$$

$$
\begin{aligned}
& \text { i: home market } \\
& \mathbf{n}: \text { destination market } \\
& \text { j: HS group }{ }^{12} \\
& M_{i j}=\text { imports of } n \text { of group } j \text { from } i . \\
& M_{n j}=\text { imports of } n \text { of group } j . \\
& M_{i t}=\text { imports of } n \text { from } i . \\
& M_{n t}=\text { total imports of } n .
\end{aligned}
$$

The GE $>1$ indicates that the country participates in the product market, in the destination country, in higher proportion than the average of its participation in that market, which means that it has a comparative advantage revealed in the good. The GE $=1$ indicates that the country participates in the product market, in the country of destination, in similar proportion to the average of its participation in that market, so it has no advantage or disadvantage

\footnotetext{
9 The data of the participation of trading partners are shown in appendices 2 and 3.

10 Agricultural and agro-industrial products correspond to chapters 0-24 and industrial products to chapters 25-99 of the Harmonized System.

11 The index is constructed to identify the degree of specialization of the products of a country in the global economy, but the document uses a variant to build the degree of specialization of the country of origin in the imports of the destination country. The described index is taken from the study developed by Universidad Nacional of Colombia. Research Center for Development CID (2007).

12 There are 16 groups which are made up of the 99 chapters of the Harmonized System
} 
revealed in that good. Finally, the GE $<1$ indicates that the country participates in the product market, in the country of destination, in a lower proportion than the average of its participation in that market, which means that it has a comparative disadvantage revealed in that good (Centro de Investigaciones para el Desarrollo [CID], 2007).

The Colombian groups that had the highest comparative advantages in 2013 are vegetable $(11,8)$, metals $(4,6)$ and food products $(4,5)$. Whereas Korea has significant comparative advantages in transportation $(7,8)$, plastic or rubber $(7,6)$, machinery and electricity $(2,3)$. By assessing the dynamics of the index, Colombia presents a GE $>1$ growing in food products, and hides and skins, while South Korea has a comparative disadvantage in these sectors $(\mathrm{GE}<1)$. In addition, vegetable shows a GE $>1$ but decreasing, which indicates that there are comparative advantages, but the participation in the market is decreasing.

Table 3. Colombia and South Korea: Revealed Comparative Advantage Index

\begin{tabular}{|c|c|c|c|c|c|c|c|}
\hline \multirow{2}{*}{ Group } & \multirow{2}{*}{$\begin{array}{l}\text { Chapters of the } \\
\text { Harmonyzed } \\
\text { System }\end{array}$} & \multicolumn{3}{|c|}{ Colombia } & \multicolumn{3}{|c|}{ South Korea } \\
\hline & & 1993 & 2003 & 2013 & 1993 & 2003 & 2013 \\
\hline Animal & $01-05$ & 0,4 & 0,3 & 1,3 & 0,0 & 1,2 & 0,1 \\
\hline Vegetable & $06-15$ & 15,2 & 6,4 & 11,8 & 0,0 & 0,0 & 0,0 \\
\hline Food Products & $16-24$ & 3,1 & 2,6 & 4,5 & 0,1 & 0,0 & 0,2 \\
\hline Minerals & $25-26$ & 0,0 & 0,2 & 0,0 & 0,0 & 0,0 & 1,2 \\
\hline Fuels & $27-27$ & 0,0 & 0,3 & 0,4 & 0,0 & 0,0 & 0,1 \\
\hline Chemicals & $28-38$ & 0,0 & 0,0 & 0,8 & 0,7 & 0,3 & 1,2 \\
\hline Plastic or Rubber & $39-40$ & 0,0 & 0,1 & 0,0 & 6,7 & 6,5 & 7,6 \\
\hline Hides and Skins & $41-43$ & 2,3 & 0,7 & 3,5 & 0,3 & 0,1 & 0,1 \\
\hline Wood & $44-49$ & 0,00 & 0,00 & 0,03 & 0,5 & 0,2 & 0,6 \\
\hline Textiles and Clothing & $50-63$ & 0,24 & 0,51 & 0,19 & 16,4 & 2,1 & 1,4 \\
\hline Footwear & $64-67$ & 0,0 & 0,5 & 0,0 & 15,4 & 0,4 & 0,1 \\
\hline Stone and Glass & $68-71$ & 0,5 & 0,0 & 0,0 & 1,2 & 0,7 & 0,4 \\
\hline Metals & $72-83$ & 4,6 & 8,1 & 4,6 & 1,3 & 0,6 & 2,6 \\
\hline Mach and Elec & $84-85$ & 0,0 & 0,0 & 0,0 & 7,8 & 2,4 & 2,3 \\
\hline Transportation & $86-89$ & 0,0 & 0,0 & 0,0 & 14,2 & 2,2 & 7,8 \\
\hline Miscellanous & $90-99$ & 0,0 & 0,0 & 0,1 & 1,0 & 1,0 & 1,0 \\
\hline
\end{tabular}

Source: Author elaboration based on WITS

Colombia has significant comparative disadvantages in the Korean market $(\mathrm{GE}=0)$ in minerals, plastic or rubber, machinery and electricity, and transportation. In contrast, South Korea had a comparative advantage in these sectors in 2013, highlighting that it has a growing GE $>1$ in plastic and rubber, noting that it presents a $\mathrm{GE}>1$ grow in plastic and rubber, but a GE $>1$ decrease in machinery and electricity, and transport. Although it has comparative 
advantages in the Colombian market, the share of these products decreased from 1993 to 2013.

From the above, it is identified that trade between the two countries is complementary; Colombia's exports to South Korea are mainly characterized by vegetable and metal products, in which it has a comparative advantage in the Korean market. Also, for fuels, it has a comparative disadvantage, but with a tendency to improve its participation. While imports from South Korea that have a comparative advantage are machinery and electricity, plastic or rubber, and transportation.

\section{RELEVANT ASPECTS OF THE FREE TRADE AGREEMENT}

The FTA signed between the Republic of Colombia and the Republic of Korea in 2013 covers trade in goods and services, and includes areas such as investment, intellectual property, cooperation, among other issues (MinCIT, 2013b). Bilateral trade in goods is governed by the General Agreement on Tariffs and Trade (GATT) ${ }^{13}$ and foreign direct investment in goods is governed by the Agreement on Trade-Related Investment Measures (TRIMs).

\section{Market for Goods}

The FTA seeks to provide preferential access to the goods of one party in the other party's market, for this reason the signatory countries agree to grant national treatment to the products and suppliers of the partner country, and the reduction or elimination of tariff and non-tariff barriers.

\section{Tariff Measures}

The elimination of tariff barriers was established as staging categories ${ }^{14}$, in effect, "neither Party shall increase any existing customs duty, or adopt any new customs duty, on an originating good" (Congress of Colombia, Law 1747, 2014). Regarding the tariff reduction for the agricultural and food supply of Colombia (MinCIT, 2013a), the dismantling of tariffs for pork and poultry meat was established in terms of 10 to 16 years, while the tariff for bovine meat and offal will be eliminated in 19 years.

For vegetable products such as flowers (roses, carnations, orchids, among others), tariffs will be eliminated in 3 and 5 years. And in fruits the tariff reduction was agreed in terms that go between 5,7 and 10 years, this term also applies to the majority of vegetables and tuberous crops. Furthermore, coffee (roasted or decaffeinated) that is the main agricultural product that Colombia 
exports to the Asian country has immediate elimination of tariffs. Likewise, there will be immediate elimination for the group of fuels, except for crude petroleum oils or bituminous minerals, which will be tax-free in three years.

South Korea will get immediate access to the Colombian market for approximately $90.0 \%$ of agricultural products, although rice and rice-containing products were excluded by both countries.

In addition, it was agreed that $98 \%$ of the tariff subheadings of the industrial sector of Colombia will be immediately tariff free to enter the Korean market (MinCIT, 2013a), while the remaining $2 \%$ that includes products such as essential oils and resinoids, and perfumery, toilet or cosmetic preparations will have a staging period of between 3, 5, 10 and 16 years; wood and cork products shall be released in 3, 5 or 10 years; products such as machinery and electrical equipment; and motor vehicles and other land vehicles, their parts and accessories, will be tariff free in 3 years.

On the other hand, Colombia decrease tariffs gradually for industrial products from South Korea, taking into account the sensitivities of certain sectors in relation to the Asian country, and releasing raw materials more quickly.

\section{Non-tariff Measures}

Countries may not exercise restrictions on the importation of goods from the partner country or the export of any merchandise destined for the territory of the other party; taxes and other export charges are also inhibited, except in cases where the tax is applied to the goods in the domestic market. Likewise, each party must notify the procedures that grant the import licenses; the systems must be simple so that they do not become an obstacle to trade.

\section{Other Measures}

As additional measures that constitute guarantees for countries are the prohibition of the introduction of subsidies to exports of agricultural goods and agricultural safeguard measures. The latter allow countries to apply a higher tariff if the amount acquired in a year exceeds an established level of activation, Korean agricultural goods covered by this measure are beef and tangerines, and for Colombia it is beef.

\section{Trade Remedies}

The agreement establishes trade remedies mechanisms for imports that cause serious damage or threat to a domestic industry that produces the same or a similar good. The established mechanis$\mathrm{ms}$ are safeguard measures for products that are being imported in increasing quantities and, anti-dumping and coun- 
tervailing measures for products that are entering the market at a price lower than their normal value.

\section{Sanitary and Phytosanitary Measures}

The Parties affirm their existing rights and obligations with respect to each other under the SPS Agreement ${ }^{15}$ which states that no country should be prevented from adopting or applying sanitary and phytosanitary measures to protect human, animal or plant life or health; but these measures should not constitute a means of arbitrary or unjustifiable discrimination hindering bilateral trade.

\section{Implications of the Aspects Negotia- ted in the FTA in Relation to Tariff Elimination}

The total exports of South Korea are characterized by industrial products. In contrast, the total exports of Colombia are focused on agricultural products and fuels, and behavior of bilateral trade is no stranger to this dynamic, since about $75 \%$ of Colombian imports from the Asian country during the period 1993-2013 belong to three groups of the industrial sector: i) machinery and electricity, ii) transportation and iii) plastic and rubber. In relation to Colombian exports to South Korea, coffee had a share of around $70 \%$ in 1993 , while it concentrated in coffee, fuels and metals in 2013.
Among the products that can increase their participation in the Korean market in the short term, are coffee (roasted or decaffeinated) and fuels, products that already have an important participation in the Korean market and for which the immediate elimination of tariffs was agreed. However, tariff reduction is progressive in most animal, plant and food products; therefore, the signed FTA shows opportunities for the agricultural and agro-industrial sector, possibly for long term.

In relation to Colombian industrial products, tariff benefits were obtained to enter the Korean market, although this fact does not imply great opportunities for national exports, given that the products of the country with export potential and comparative advantage are mainly from the primary sector. However, the immediate tariff elimination in most chemical products can have a positive effect on trade, since they have a growing $\mathrm{RCA}<1$, which indicates that in the period studied they gained participation. In addition, the immediate elimination of the tariff was agreed upon for most of the tariff items of the metals group, products that already have a comparative advantage in the Korean market.

In the same line, the immediate elimination of tariffs was established for $90 \%$ of the agricultural tariff items that seek

$\overline{15}$ Agreement on the Application of Sanitary and Phytosanitary Measures contained in Appendix 1A of the WTO Agreement. 
to enter Colombia from South Korea; however, the Asian country does not specialize in the sale of these products and have a comparative disadvantage in the Colombian market according to the RCA Index.

Finally, it is emphasized that the Korean economy specializes in the production and export of industrial goods, and the purpose of the Colombian government is to focus on strengthening small and medium-sized Colombian companies, by giving them the opportunity to access these goods with lower tariffs; nonetheless, bearing in mind that the reduction of tariffs may affect domestic companies with low competitiveness, most industrial products shall be released progressively.

\section{DETERMINANTS OF SOUTH KO- REA'S TRADE FLOWS}

\section{Theoretical Model of the Gravity Equation}

The study of the determinants of trade flows of South Korea and the approximation of the effect of the entry into force of the FTA on bilateral trade, is carried out through the theoretical model developed by Anderson \& Van Wincoop (2003). The model is based on the following assumptions. Consumers maximize the function:

$$
\left(\sum_{i} \beta_{i, j}^{(1-\sigma) / \sigma} c_{i, j}^{(\sigma-1) / \sigma}\right)^{\frac{\sigma}{(\sigma-1)}}
$$

The elasticity of substitution between the goods is given by $\sigma$. Parameter $\beta_{i}$ can be interpreted as the preferences of consumers towards the goods of the different countries or the quality of the goods produced in a certain country $c_{i, j}$, represents the quantities consumed of the good produced in $\mathrm{i}$ by a consumer in $\mathrm{j}$.

Consumers maximize the utility function subject to budget constraint:

$$
\sum_{i} p_{i, j} c_{i, j}=y_{j}
$$

$p_{i, j}$ is the price in the country $\mathrm{j}$ from the good produced in $i$, including the price of the good with factory costs (and the commercial costs between $\mathrm{i}$ and $\mathrm{j}\left(\tau_{i, j}\right)$. And $y_{j}$ represents the nominal income of the residents of the country $\mathrm{j}$.

The nominal value of exports from $\mathrm{i}$ to $\mathrm{j}$ is $X_{i, j}=p_{i, j} c_{i, j}$. And the income of country i must be equal to $y_{i}=\sum_{j} x_{i, j}$. The nominal demand of the good of the region $i$ by consumers in region $j$ is given by:

$$
X_{i, j}=\left(\frac{\beta_{i} p_{i} \tau_{i j}}{P_{j}}\right)^{(1-\sigma)} y_{j}
$$

Where $P_{j}$ is the theoretical price index of $\mathrm{j}$ :

$$
P_{j}=\left[\sum_{i}\left(\beta_{i} p_{i} \tau_{i, j}\right)^{(1-\sigma)}\right]^{\frac{1}{1-\sigma}}
$$


The equilibrium condition ensures the market clearing. Given by $y_{i}=\sum_{j} x_{i, j}$. Replacing the demands we obtained:

$$
y_{i}=\left(\beta_{i} p_{i}\right)^{(1-\sigma)} \sum_{j}\left(\left(\frac{\tau_{i, j}}{P_{j}}\right)^{(1-\sigma)}\right) y_{j}, \forall i
$$

From the condition of market clearing (Equation 6) and setting the units so that all prices $p_{i}$ are equal to 1 , the coefficients $\beta_{i}$ are obtained. World nominal income is defined as $y^{W} \equiv \sum_{j} y_{j}$ and the shares in the income $\theta_{j} \equiv \frac{y_{i}}{y^{W}}$.

$$
X_{i, j}=\frac{y_{i} y_{j}}{y^{W}}\left(\frac{\tau_{i, j}}{\Pi_{i} P_{j}}\right)^{(1-\sigma)}
$$

Where:

$$
\begin{aligned}
\Pi_{i} & =\left(\sum_{j}\left(\frac{\tau_{i, j}}{P_{j}}\right)^{1-\sigma} \theta_{i}\right)^{\frac{1}{1-\sigma}} \\
P_{j} & =\left[\sum_{i}\left(\frac{\tau_{i, j}}{\Pi_{j}}\right)^{1-\sigma} \theta_{j}\right]^{\frac{1}{1-\sigma}}
\end{aligned}
$$

[8] and [9] can be solved for all $\Pi_{i}^{\prime} s$ and $P_{j}^{\prime} s$ in terms of income shares, bilateral trade barriers and $\sigma$. It is assumed that the trade costs between $i$ and $j$ are symmetric, thus, $\tau_{i, j}=\tau_{j, i}$. Under symmetry it can be verified that a solution for [8] and [9] is $\Pi_{i}=P_{j}$ with

$$
P_{j}^{1-\sigma}=\sum_{i} P_{i}^{\sigma-1} \theta_{i} t_{i j}^{1-\sigma}
$$

Based on these conditions, bilateral trade flows can be expressed in terms of nominal income, trading costs and the theoretical price indexes:

$$
X_{i, j}=\frac{y_{i} y_{j}}{y^{W}}\left(\frac{\tau_{i, j}}{P_{i} P_{j}}\right)^{(1-\sigma)}
$$

Being the basic gravity model (11) subject to (10). The key finding of the Anderson \& Van Wincoop model (2003) is that bilateral trade is determined by relative trade costs, that is, "the propensity of country $j$ to import from country $i$ is determined by country $j$ 's trade cost toward i relative to its overall "resistance" to imports (weighted average trade costs) and to the average "resistance" facing exporters in country 1; not simply by the absolute trade costs between countries i and j".

\section{Methodology}

Gravity model estimation is attained using a panel data that relates the trade flows of South Korea with economic, geographical, cultural and commercial variables of the Asian country and its commercial partners for the period 1993-2013. The estimate of exports uses 140 trading partners and for imports 126 trading partners. In addition, estimates are made for sectoral data, first, agricultural and agro-industrial products are studied, which correspond to the first 24 chapters of the Harmonized System; secondly, industrial products, corresponding to chapters 25 to 99 . 
From equation [11] a log-linear equation is obtained, estimates are made for fixed effects and random effects so that the estimation method is consistent with the theoretical predictions, given that it allows explaining the terms of multilateral resistance. The log-linear equation resulting from the Anderson \& Van Wincoop model is:

$$
\ln X_{i j t}=\beta_{0}+\beta_{1} \ln Y_{i t}+\beta_{2} \ln Y_{j t}+\beta_{3} \ln \tau_{i j}+\beta_{4} \ln \Pi_{i}+\beta_{5} \ln P_{j}
$$

The econometric specification of equation (12) for exports and imports is:

$$
\begin{aligned}
& \ln X_{i j t}=\beta_{0}+\beta_{1} \ln Y_{i t}+\beta_{2} \ln Y_{j t}+\beta_{3} \ln \tau_{i j}+\beta_{4} \ln \Pi_{i}+\beta_{5} \ln P_{j}+\mu_{i j t} \\
& \ln M_{i j t}=\beta_{0}+\beta_{1} \ln Y_{i t}+\beta_{2} \ln Y_{j t}+\beta_{3} \ln \tau_{i j}+\beta_{4} \ln \Pi_{i}+\beta_{5} \ln P_{j}+\mu_{i j t}
\end{aligned}
$$

$\mathrm{X}_{\mathrm{ij}}$, and $\mathrm{M}_{\mathrm{ij}}$ represent the exports and imports of country $i$ in year $t ; Y_{i}$ and $Y_{j}$ are the GDP of the exporting and importing country, respectively. $\tau_{\mathrm{ij}}$, represents trade costs between countries, and $\mu_{\mathrm{ij}}$ is the random error term. The terms $\beta$ are the coefficients to be estimated, being the term $\beta_{0}$ a constant of the regression.
The specification of the trade cost function for estimation purposes includes a number of additional variables to the physical distance, which are used as controls because they are considered to influence trade costs. The cost function is specified as:

$$
\log \tau_{i j}=b_{1} \log \text { Dist }_{i j}+b_{2} \text { Leng }_{\text {com }_{i j}}+b_{3} \text { Colony }+b_{4} \text { Landlocked }_{j}
$$

The variables from $b_{2}$ to $b_{4}$ of equation 15 are Dummies ${ }^{16}$ indicating countries with a common language, countries with colonial ties and landlocked countries, respectively. Also, to evaluate the impact of free trade agreements, the variable FTA is included in the equation. In effect, the equations to be estimated are $^{17}$ :

$$
\begin{aligned}
& \ln X_{i j t}=\beta_{0}+\beta_{1} \ln Y_{i t}+\beta_{2} \ln Y_{j t}+\beta_{3} \ln \tau_{i j}+\beta_{4} \ln \Pi_{i}+\beta_{5} \ln P_{j}+\beta_{6} F T A_{t}+\mu_{i j t} \\
& \ln M_{i j t}=\beta_{0}+\beta_{1} \ln Y_{i t}+\beta_{2} \ln Y_{j t}+\beta_{3} \ln \tau_{i j}+\beta_{4} \ln \Pi_{i}+\beta_{5} \ln P_{j}+\beta_{6} F T A_{t}+\mu_{i j t}
\end{aligned}
$$

\footnotetext{
16 These variables take two values, usually zero and one. The values mean that the observation belongs to one of two categories.

17 The list of variables with description and source is in Appendix 6.
} 
As mentioned above, the estimation is made using fixed effects and random effects models, which assuming that the interception is not the same, they shape the individual character of the countries. In addition, as so-called multilateral resistance terms are not directly observable, these models are used as an alternative to approximate these terms and achieve theoretical consistency. The Wooldridge test was carried out to identify the presence of autocorrelation. Wooldridge test evidences autocorrelation problems in all panels data (See Appendix 7), which are corrected through fixed and random effects models with autoregressive term ( $\rho$ ) of degree 1 (AR1) that controls the dependence of $t$ with respect to $t-1$.

\section{RESULTS}

\section{Gravity Model for Exports}

The results of the estimates for total and sectoral exports are presented in tables 4 and 5, respectively. In relation to total exports, it was found that the GDP of the partner country is a significant determinant and has a positive influence on exports from South Korea, its GDP also has a positive effect but of smaller magnitude. Specifically, increase of $1.0 \%$ of the GDP of a partner country increases Korean exports by $1.12 \%$, while $1 \%$ increase in South Korea's GDP increases its exports by $0.20 \%$. Described above coincides with the evidence in the data, as the main destinations of exports of the Asian country are China, the United States and Japan, countries that in 2013 presented the highest nominal GDP worldwide according to the ranking of the International Monetary Fund (IMF).

Table 4. Determinants of South Korea's Total Exports

\begin{tabular}{cccc}
\hline & \multicolumn{3}{c}{ Dependent Variable: In_exports } \\
\cline { 2 - 4 } Independent Variable & $\begin{array}{c}(1) \\
\text { Pooled OLS }\end{array}$ & $\begin{array}{c}(\mathbf{2}) \\
\text { Fixed Effect }\end{array}$ & $\begin{array}{c}\text { (3) } \\
\text { Fixed Effect with } \\
\text { autocorrelation correction }\end{array}$ \\
\hline In_gdp_corea & $0,510^{* * *}$ & $0,460^{* *}$ & $0,200^{* *}$ \\
& $(7,24)$ & $(2,83)$ & $(2,79)$ \\
In_gdp_socio & $0,887^{* * *}$ & $0,956^{* * *}$ & $1,012^{* * *}$ \\
In_dist & $(62,49)$ & $(10,44)$ & $(18,67)$ \\
leng_com & $-0,900^{* * *}$ & 0 & 0 \\
colony ties & $(-17,90)$ & $()$. & $()$. \\
& $0,481^{* * *}$ & 0 & 0 \\
& $(8,84)$ & $()$. & $()$. \\
& $-1,335^{* * *}$ & 0 & 0 \\
\end{tabular}


Table 4 - continued from previous page

\begin{tabular}{cccc}
\hline & \multicolumn{3}{c}{ Dependent Variable: In_exports } \\
\cline { 2 - 4 } Independent Variable & $\begin{array}{c}(\mathbf{1}) \\
\text { Pooled OLS }\end{array}$ & $\begin{array}{c}(\mathbf{2}) \\
\text { Fixed Effect }\end{array}$ & $\begin{array}{c}\text { Fixed Effect with } \\
\text { autocorrelation correction }\end{array}$ \\
\hline landlocked & $-0,927^{* * *}$ & 0 & 0 \\
& $(-14,39)$ & $()$. & $()$. \\
FTA & 0,193 & $-0,0338$ & 0,0023 \\
& $(1,63)$ & $(-0,33)$ & $(0,03)$ \\
Constant & $-5,644^{* * *}$ & $-13,96^{* * *}$ & $-9,570^{* * *}$ \\
& $(-4,09)$ & $(-6,53)$ & $(-22,10)$ \\
\hline \multicolumn{1}{c}{$\mathbf{N}$} & & $\mathbf{2 9 4 0}$ & $\mathbf{2 8 0 0}$ \\
\hline$t$ statistics in parentheses & & & \\
${ }^{*} \mathrm{p}<0.05,{ }^{* *} \mathrm{p}<0.01,{ }^{* * *} \mathrm{p}<0.001$ & & & \\
\hline
\end{tabular}

Source: Author elaboration.

Regarding with the results predicted by the theoretical gravity model, the distance has a negative and significant influence on exports from South Korea, the $1 \%$ increase in the distance between countries decreases the flow of exports by $0.90 \%$. In addition, this coincides with the fact that South Korea mainly trades with Asian countries.

In addition, having a common language stimulates bilateral trade and the parameter turns out to be significant.
Thus, South Korea exports approximately $0.62 \%$ more to countries in which at least $9.0 \%$ of the population have a common language with South Korea ${ }^{18}$, whereas the absence of littoral (landlocked) affects in a negative way the commercial flows. Finally, the colony and FTA variables show signs contrary to the expected and are not significant; thus, free trade agreements do not determine the exports of the Asian country.

18 The equation elasticity $=\exp (a)-1$ is applied to the dummy variables to be interpreted as elasticity, where "a" is the estimated coefficient. 
Table 5. Determinants of South Korea's Sectoral Exports

\begin{tabular}{cccc}
\hline & \multicolumn{3}{c}{ In_expo_primary } \\
\cline { 2 - 4 } $\begin{array}{c}\text { Independent } \\
\text { Variable }\end{array}$ & $\begin{array}{c}(\mathbf{1}) \\
\text { Pooled } \\
\text { OLS }\end{array}$ & $\begin{array}{c}(\mathbf{2}) \\
\text { Fixed Effect }\end{array}$ & $\begin{array}{c}\text { (3) } \\
\text { Fixed Effect with } \\
\text { autocorrelation } \\
\text { correction }\end{array}$ \\
\hline In_gdp_corea & $0,367^{* * *}$ & $-0,0939$ & $-0,252$ \\
& $(3,56)$ & $(-0,49)$ & $(-1,76)$ \\
In_gdp_socio & $0,727^{* * *}$ & $1,103^{* * *}$ & $1,169^{* * *}$ \\
& $(38,53)$ & $(7,36)$ & $(10,56)$ \\
In_dist & $-1,832^{* * *}$ & 0 & 0 \\
leng_com & $(-27,19)$ & $()$. & $()$. \\
& $0,480^{* * *}$ & 0 & 0 \\
colony & $(5,67)$ & $()$. & $()$. \\
& $0,413^{*}$ & 0 & 0 \\
landlocked & $(2,42)$ & $()$. & $()$. \\
& $-0,747^{* * *}$ & 0 & 0 \\
FTA & $(-5,67)$ & $()$. & $()$. \\
& 0,160 & 0,209 & $0,296^{*}$ \\
Constant & $(1,1)$ & $-1,31$ & $-2,19$ \\
& 3,163 & $-17,52^{* * *}$ & $-14,79^{* * *}$ \\
\hline N & $(1,47)$ & $(-4,77)$ & $(-12,20)$ \\
\hline
\end{tabular}

\begin{tabular}{ccc}
\hline \multicolumn{3}{c}{ In_expo_industrial } \\
\hline $\begin{array}{c}\text { Pooled } \\
\text { OLS }\end{array}$ & $\begin{array}{c}\text { Fixed } \\
\text { Effect }\end{array}$ & $\begin{array}{c}\text { Fixed Effect with } \\
\text { autocorrelation } \\
\text { correction }\end{array}$ \\
\hline $0,512^{* * *}$ & $0,461^{* *}$ & $0,214^{* *}$ \\
$(7,14)$ & $(2,81)$ & $(2,92)$ \\
$0,893^{* * *}$ & $0,965^{* * *}$ & $1,021^{* * *}$ \\
$(62,43)$ & $(10,39)$ & $(18,4)$ \\
$-0,877^{* * *}$ & 0 & 0 \\
$(-17,40)$ & $()$. & $()$. \\
$0,476^{* * *}$ & 0 & 0 \\
$(8,68)$ & $()$. & $()$. \\
$-1,403^{* * *}$ & 0 & 0 \\
$(-11,88)$ & $()$. & $()$. \\
$-0,944^{* * *}$ & 0 & 0 \\
$(-14,21)$ & $()$. & $()$. \\
0,187 & $-0,0434$ & $-0,0062$ \\
$(1,56)$ & $(-0,43)$ & $(-0,08)$ \\
$-6,008^{* * *}$ & $-23,99^{* * *}$ & $-18,55^{* * *}$ \\
$(-4,28)$ & $(-8,45)$ & $(-31,10)$ \\
\hline & $\mathbf{2 8 9 8}$ & $\mathbf{2 7 6 0}$ \\
\hline
\end{tabular}

t statistics in parentheses

${ }^{*} p<0.05,{ }^{* *} p<0.01,{ }^{* * *} p<0.001$

Source: Author elaboration.

The exports of the primary sector of South Korea are positively and significantly determined by the GDP of the partner country, while the Korean GDP has a positive effect but minor and not significant. The distance and landlocked variables affect South Korea's agricultural exports negatively and significantly. Furthermore, the effect of a trade agreement captured by the FTA variable is positive and significant in the estimation with autocorrelation correction.
The industrial exports are positively and significantly determined by the GDP of South Korea and its commercial partner. The effect of the distance and landlocked variables is negative. This due to the fact that the distance and the absence of maritime limits in a country significantly increase transport costs. Finally, free trade agreements have an opposite sign to that expected and the results are not statistically significant. 


\section{Gravity Model for Imports}

The results of the estimates for total and sectoral imports are presented in the tables 6 and 7, respectively.

Table 6. Determinants of South Korea's Total Imports

\begin{tabular}{cccc}
\hline & \multicolumn{3}{c}{ Dependent Variable: In_imports } \\
\cline { 2 - 4 } Independent Variable & $\begin{array}{c}(\mathbf{1}) \\
\text { Pooled OLS }\end{array}$ & $\begin{array}{c}(\mathbf{2}) \\
\text { Fixed Effect }\end{array}$ & $\begin{array}{c}(\mathbf{3}) \\
\text { Fixed Effect with } \\
\text { autocorrelation correction }\end{array}$ \\
\hline In_gdp_corea & $0,254^{*}$ & $1,270^{* * *}$ & $1,414^{* * *}$ \\
& $(2,57)$ & $(6,15)$ & $(10,58)$ \\
In_gdp_socio & $1,116^{* * *}$ & $0,339^{*}$ & $0,280^{* *}$ \\
& $(65,98)$ & $(2,17)$ & $(2,83)$ \\
In_dist & $-0,862^{* * *}$ & 0 & 0 \\
& $(-13,12)$ & $()$. & $()$. \\
leng_com & 0,0921 & 0 & 0 \\
& $(1,16)$ & $()$. & $()$. \\
colony & $-0,822^{* * *}$ & 0 & 0 \\
& $(-5,19)$ & $()$. & $()$. \\
landlocked & $-0,792^{* * *}$ & 0 & 0 \\
& $(-7,63)$ & $()$. & $()$. \\
FTA & $0,704^{* * *}$ & $0,339^{*}$ & 0,192 \\
& $(5,25)$ & $(2,38)$ & $(1,36)$ \\
Constant & $-5,687^{* *}$ & $-20,83^{* * *}$ & $-22,71^{* * *}$ \\
& $(-2,73)$ & $(-7,55)$ & $(-26,11)$ \\
\hline $\mathbf{N}$ & & $\mathbf{2 6 4 6}$ & $\mathbf{2 5 2 0}$ \\
\hline
\end{tabular}

t statistics in parentheses

${ }^{*} p<0.05,{ }^{* *} p<0.01,{ }^{* * *} p<0.001$

Source: Author elaboration

The GDP of the importing country and the exporting country determine positively and significantly the South Korea's total imports, because an increase of $1 \%$ of Korean GDP and GDP of its trading partner increases Korea's external purchases by $1,41 \%$ and $0,28 \%$, respec- tively. The variable FTA also positively determines imports from the Asian country, but the result is not significant.

The distance variable determines the total imports of South Korea, negative and significantly according to the results (OLS estimation), because this variable is eliminated in the fixed effects model. 
Table 7. Determinants of South Korea's Sectoral Imports

\begin{tabular}{|c|c|c|c|c|c|c|}
\hline \multirow[b]{2}{*}{$\begin{array}{l}\text { Independent } \\
\text { Variable }\end{array}$} & \multicolumn{3}{|c|}{ In_impo_primary } & \multicolumn{3}{|c|}{ In_impo_industrial } \\
\hline & $\begin{array}{l}\text { (1) } \\
\text { Pooled } \\
\text { OLS }\end{array}$ & $\begin{array}{c}(2) \\
\text { Fixed Effect }\end{array}$ & $\begin{array}{l}\text { (3) } \\
\text { Fixed Effect with } \\
\text { autocorrelation } \\
\text { correction }\end{array}$ & $\begin{array}{c}\text { (1) } \\
\text { Pooled OLS }\end{array}$ & $\begin{array}{c}(2) \\
\text { Fixed Effect }\end{array}$ & $\begin{array}{l}\text { (3) } \\
\text { Fixed Effect with } \\
\text { autocorrelation } \\
\text { correction }\end{array}$ \\
\hline In_gdp_corea & $\begin{array}{l}0,341^{*} \\
(2,49)\end{array}$ & $\begin{array}{c}1,058^{* * *} \\
(4,56)\end{array}$ & $\begin{array}{c}0,873^{* * *} \\
(6,21)\end{array}$ & $\begin{array}{l}0,218 \\
(1,92)\end{array}$ & $\begin{array}{c}1,266^{* * *} \\
(6,23)\end{array}$ & $\begin{array}{c}1,479^{* * *} \\
(9,94)\end{array}$ \\
\hline In_gdp_socio & $\begin{array}{c}0,898^{\star * *} \\
(40,13)\end{array}$ & $\begin{array}{l}0,391 \\
(1,86)\end{array}$ & $\begin{array}{c}0,406^{* * *} \\
(3,37)\end{array}$ & $\begin{array}{l}1,118^{* * *} \\
(55,45)\end{array}$ & $\begin{array}{l}0,325 \\
(1,94)\end{array}$ & $\begin{array}{l}0,186 \\
(1,74)\end{array}$ \\
\hline In_dist & $\begin{array}{c}-0,545^{\star * *} \\
(-6,04)\end{array}$ & $\begin{array}{l}0 \\
(.)\end{array}$ & $\begin{array}{l}0 \\
(.)\end{array}$ & $\begin{array}{c}-1,126^{* * *} \\
(-15,37)\end{array}$ & $\begin{array}{l}0 \\
(.)\end{array}$ & $\begin{array}{l}0 \\
(.)\end{array}$ \\
\hline leng_com & $\begin{array}{l}0,295^{* *} \\
(2,83)\end{array}$ & $\begin{array}{l}0 \\
(.)\end{array}$ & $\begin{array}{l}0 \\
(.)\end{array}$ & $\begin{array}{l}0,219^{*} \\
(2,42)\end{array}$ & $\begin{array}{l}0 \\
(.)\end{array}$ & $\begin{array}{l}0 \\
(.)\end{array}$ \\
\hline colony & $\begin{array}{c}-1,270^{* * *} \\
(-6,25)\end{array}$ & $\begin{array}{l}0 \\
(.)\end{array}$ & $\begin{array}{l}0 \\
(.)\end{array}$ & $\begin{array}{c}-1,091^{* * *} \\
(-6,20)\end{array}$ & $\begin{array}{l}0 \\
(.)\end{array}$ & $\begin{array}{l}0 \\
(.)\end{array}$ \\
\hline landlocked & $\begin{array}{c}-0,994^{* * *} \\
(-6,56)\end{array}$ & $\begin{array}{l}0 \\
(.)\end{array}$ & $\begin{array}{l}0 \\
(.)\end{array}$ & $\begin{array}{c}-0,660^{* * *} \\
(-5,28)\end{array}$ & $\begin{array}{l}0 \\
(.)\end{array}$ & $\begin{array}{l}0 \\
(.)\end{array}$ \\
\hline FTA & $\begin{array}{c}0,805^{* * *} \\
(5,24)\end{array}$ & $\begin{array}{c}0,300^{*} \\
(2,16)\end{array}$ & $\begin{array}{l}0,239 \\
(1,91)\end{array}$ & $\begin{array}{c}0,785^{* * *} \\
(5,40)\end{array}$ & $\begin{array}{l}0,370^{*} \\
(2,50)\end{array}$ & $\begin{array}{l}0,238 \\
(1,59)\end{array}$ \\
\hline Constant & $\begin{array}{l}-9,118^{* *} \\
(-3,02)\end{array}$ & $\begin{array}{c}-19,28^{* * *} \\
(-5,87)\end{array}$ & $\begin{array}{c}-15,72^{* * *} \\
(-19,29)\end{array}$ & $\begin{array}{l}-2,852 \\
(-1,19)\end{array}$ & $\begin{array}{c}-20,52^{* * *} \\
(-7,57)\end{array}$ & $\begin{array}{c}-22,43^{* * *} \\
(-21,60)\end{array}$ \\
\hline $\mathbf{N}$ & & 1533 & 1460 & & 2457 & 2340 \\
\hline
\end{tabular}

t statistics in parentheses

${ }^{*} p<0.05,{ }^{* *} p<0.01,{ }^{* * *} p<0.001$

Source: Author elaboration

The gravity model for primary imports indicates that they are positively and significantly determined by the income of South Korea and the exporting country. The FTA also determines positively the external purchases of agricultural products, although the effect presented is not significant. Finally, imports of industrial products are determined positively and significantly by the GDP of South Korea; although the distance has a negative and significant effect on the country's industrial imports. In relation to the free trade agreement, it has a positive, but not a significant effect.

\section{CONCLUSIONS}

The main objective of this document is to study the factors that determine trade between Colombia and the Republic of Korea. South Korea is characterized by the rapid growth of its economy, a population with a high GDP per capita, and an opening rate of around $90.0 \%$. The Asian country's exports are mainly based on products of the industrial 
sector (capital goods), specifically machinery, electricity and transport, while Colombia's exports are currently concentrated in fuels (raw materials) and agricultural products such as coffee.

The bilateral trade of Colombia and South Korea is marginal and it has an inter-industrial character, with a deficit trade balance for Colombia. Colombia has comparative advantages revealed in food and vegetable products, and in the FTA it was agreed to eliminate immediate tariffs on products such as coffee and fuels that already have a significant share in South Korea. Nevertheless, tariff reductions in the Korean market are progressive for most agricultural products. Also, it was agreed to immediately reduce $98.0 \%$ of Colombia's industrial tariff headings; however, the country has no comparative advantage in most products in this sector.

The main interest of Colombia in signing the FTA lay in having access to a preferential market for Colombian agricultural and agro-industrial products, and what has been agreed in terms of tariff reduction can lead to the fulfillment of this objective in the long term, since there is an immediate elimination of tariffs for the products that are most commercialized in the Korean market, although the reduction is progressive in most products. Therefore, there are no incentives to diversify the country's export basket in the short term. In relation to the industrial products of South Korea, the established tariff reduction periods are broad for sensitive Colombian sectors such as automotive (and auto parts), although currently about $40.0 \%$ of Colombian imports from South Korea correspond to the chapter on vehicles and their parts.

Based on the results of the gravity model, the hypothesis that economic variables such as GDP and geographical variables such as distance determine trade flows between South Korea and its partners are accepted. On one hand, it was found that the total and sectorial trade flows are determined positively with the income of the exporting and importing country, highlighting that the GDP of the buyer country has a higher effect on trade than the GDP of the selling country.

On the other hand, the distance used as a proxy for commercial costs has an inverse relationship with bilateral trade. This indicates the importance of improvement in road and port infrastructure that contributes to the reduction of transport costs, and therefore, to boost exports. In addition, having a common language increases the total exports of South Korea. In this sense, it is important to implement strategies to increase the percentage of the population that speaks English in order to facilitate the information search and customers acquisition in the partner country. 
The coefficients that measure the effect of free trade agreements on exports of South Korea are not significant and the sign is contrary to what is expected, although the entry into force of a trade agreement has a positive influence on imports from the Asian country, which implies possibilities of increasing Colombian exports to the Korean market.

The FTA went into effect in 2016, so both positive and negative effects can be evaluated in the long term. In this sense, the study of both positive and negative impacts for Colombia became the sub- ject of a new investigation. However, undoubtedly the reduction of tariff and non-tariff barriers will not work on their own, and the effects for Colombia will depend to a large extent on the putting into practice of economic and commercial policies focused on improving road infrastructure, industrialization and competitiveness.

\section{CONFLICT OF INTEREST STATEMENT}

The autor declare that does not exist an interest conflict. 


\section{REFERENCES}

Anaman, K. \& Al-Kharusi, L. (2003). An Analysis of Trade Flows between Brunei Darussalam and the European Union. ASEAN Economic Bulletin, 20, 60-72. https://doi.org/10.1355/AE20-1E

Anderson, J. \& Van Wincoop, E. (2003). Gravity with Gravitas: A Solution to the Border Puzzle. The American Economic Review, 93, 170-192. https://doi. org/10.1257/000282803321455214

Bergstrand, J. (1985). The Gravity Equation in International Trade: Some Microeconomic Foundations and Empirical Evidence. The Review of Economics and Statistics, 67, 474-481. https://doi.org/10.2307/1925976

Bergstrand, J. (1989). The generalized gravity equation, monopolistic competition, and the factor-proportions theory in international trade. The Review of Economics and Statistics, 71, 143-153. https://doi.org/10.2307/1928061

Centro de Investigaciones para el Desarrollo (CID). (2007). Impacto del TLC en el departamento de Cundinamarca. CID.

Congreso de la República de Colombia. (2014, 26 de dic.). Ley 174 de 2012. Por medio de la cual se aprueba el Acuerdo de libre comercio entre la República de Colombia y la República de Corea. http://www.tlc.gov.co/publicaciones/733/ acuerdode_libre_comercio_entre_la_republica_de_colombia_y_la_republica_de_corea

Deardorff, A. (1998). Determinants of Bilateral Trade: Does Gravity Work in a Neoclassical World? National Bureau of Economic Research, 7-32.

Dixit, A. (1989). Entry and Exit Decisions under Uncertainty. Journal of Political Economy, 97620-638. https://doi.org/10.1086/261619

Evenett, S. \& Keller, W. (2002). On Theories Explaining the Success of the Gravity Equation. Journal of Political Economy, 110, 281-316. https://doi. org/10.1086/338746

Hellvin, L. \& Nilsson, L. (2000). Trade Flows between Trading Blocs: The Case of the EU's Trade with Asia and NAFTA. Discussion Paper. 
Helpman, E. \& Krugman, P. (1985). Market Structure and Foreign Trade: Increasing Returns, Imperfect Competition and the International Economy. The MIT Press.

Helpman, E., Melitz, M. \& Rubinstein, Y. (2008). Estimating Trade Flows: Trading Partners and Trading Volumes. Quarterly Journal of Economics, 123441-487. https://doi.org/10.1162/qjec.2008.123.2.441

Krugman, P. (1980). Scale Economies, Product Differentiation and the Pattern of Trade. American Economic Association, 70, 950-959.

Krugman, P. (1981). Intraindustry Specialization and the Gains From Trade. The Journal of Political Economy, 89, 959-973. https://doi.org/10.1086/261015

Krugman, P. (1983). New Theories of Trade among Industrial Countries. The American Economic Review, 73, 343-347.

Krugman, P. \& Obstfeld, M. (2005). Economía internacional. Teoría y política. Pearson Educación.

Melitz, M. (2003). The Impact of Trade on Intra-Industry Reallocations and Aggregate Industry Productivity. Econometrica, 71, 1695-1725. https://doi. org/10.1111/1468-0262.00467

Ministerio de Comercio, Industria y Turismo. (2010). Corea del Sur: dinámica comercial y relaciones bilaterales con Colombia. Documentos OEE-04. Oficina de Estudios Económicos.

Ministerio de Comercio, Industria y Turismo. (2013a). 100 preguntas del TLC con Corea . http://www.mincit.gov.co/publicaciones.php?id=3292\&dPrint=1

Ministerio de Comercio, Industria y Turismo. (2013b). Acuerdo de Libre Comercio entre la República de Colombia y la República de Corea. http://www.tlc.gov. co/publicaciones.php?id=733

Reina, M., Salamanca, C. \& Forero, D. (2009). Factibilidad de un Tratado de Libre Comercio entre Colombia y la República de Corea. Working Paper 49. Fedesarrollo.

Tinbergen, J. (1962). Shaping the World Economy; Suggestions for an International Economic Policy. Twenty Century Fund. 


\section{Appendices}

Appendix 1. Product Groups According to the Chapters of the Harmonized System

\begin{tabular}{|c|c|}
\hline Product Group & Chapters of the harmonized system that make up the groups \\
\hline Animal & $01,02,03,04,05$ \\
\hline Vegetable & $06,07,08,09,10,11,12,13,14,15$ \\
\hline Food Products & $16,17,18,19,20,21,22,23,24$ \\
\hline Minerals & 25,26 \\
\hline Fuels & 27 \\
\hline Chemicals & $28,29,30,31,32,33,34,35,36,37,38$ \\
\hline Plastic or Rubber & 39,40 \\
\hline Hides and Skins & $41,42,43$ \\
\hline Wood & $44,45,46,47,48,49$ \\
\hline Textiles and Clothing & $50,51,52,53,54,55,56,57,58,59,60,61,62,63$ \\
\hline Footwear & $64,65,66,67$ \\
\hline Stone and Glass & $68,69,70,71$ \\
\hline Metals & $72,73,74,75,76,78,79,80,81,82,83$ \\
\hline Mach and Elec & 84,85 \\
\hline Transportation & $86,87,88,89$ \\
\hline Miscellanous & $90,91,92,93,94,95,96,97,98,99$ \\
\hline
\end{tabular}

Source: Author elaboration based on WITS

Appendix 2. Colombia: Main Export and Import Products (2013)

\begin{tabular}{llc}
\hline Code & \multicolumn{1}{c}{ Products } & $\%$ \\
\hline & Export & 47,0 \\
$\mathbf{2 7 0 9 0 0}$ & Oils; petroleum oils and oils obtained from bituminous minerals, crude & 10,6 \\
$\mathbf{2 7 0 1 1 2}$ & Coal; bituminous, whether or not pulverised, but no agglomarated & 7,4 \\
$\mathbf{2 7 1 0 0 0}$ & Oils; petroleum oils and oils obtained from bituminous minerals, not crude; (..) & 3,2 \\
$\mathbf{0 9 0 1 1 1}$ & Coffe; not roasted or decaffeinated & 3,5 \\
$\mathbf{7 1 0 8 1 2}$ & Metals; gold, non-monetary, unwrought (but not powder) & 71,8 \\
& Total & 10,7 \\
& Import & 2,9 \\
$\mathbf{2 7 1 0 0 0}$ & Oils; petroleum oils and oils obtained from bituminous minerals, not crude; (..) & 2,6 \\
$\mathbf{8 7 0 3 2 3}$ & Vehicles; with only spark-ignition internal combustion reciprocating piston engine,(...) \\
$\mathbf{8 5 2 5 2 0}$ & Transmission apparatus; for radio-telephony, radio-telegraphy, radio broadcasting (...) & 2,6 \\
$\mathbf{8 8 0 2 4 0}$ & Aeroplanes and other aircraft; of an unladen weight exceeding 15.000 kg & 2,3 \\
$\mathbf{8 4 7 1 2 0}$ & Data processing machines; digital automatic, containing in the same housing (...) & 2,3 \\
\hline & Total & 20,9 \\
\hline
\end{tabular}

Source: Author elaboration based on WITS 
Appendix 3. South Korea: Main Export and Import Products (2013)

\begin{tabular}{|c|c|c|}
\hline Code & Products & $\%$ \\
\hline & Export & \\
\hline 271000 & Oils; petroleum oils and oils obtained from bituminous minerals, not crude; (...) & 9,1 \\
\hline 854219 & Electronic circuits; monolithic, integrated, digital, other, & 8,4 \\
\hline 870323 & Vehicles; with only spark-ignition internal combustion reciprocating piston engine,(...) & 4,9 \\
\hline 901380 & Optical devices, appliances and instruments; (...) & 4,4 \\
\hline \multirow[t]{3}{*}{890190} & Vessels; n.e.s. In heading no. 8901 , for the transport of goods and other vessels (...) & 2,6 \\
\hline & Total & 29,4 \\
\hline & Import & \\
\hline 270900 & Oils; petroleum oils and oils obtained from bituminous minerals, crude & 19,3 \\
\hline 271111 & Petroleum gases and other gaseous hydrocarbons; liquefied, natural gas & 5,9 \\
\hline 271000 & Oils; petroleum oils and oils obtained from bituminous minerals, not crude; (...) & 5,6 \\
\hline 854219 & Electronic circuits; monolithic, integrated, digital, other, & 5,4 \\
\hline \multirow[t]{2}{*}{270112} & Coal; bituminous, whether or not pulverised, but no agglomarated & 2,3 \\
\hline & Total & 38,4 \\
\hline
\end{tabular}

Source: Author elaboration based on WITS

Appendix 4. Colombia's Main Exports to South Korea by Chapters

\begin{tabular}{|c|c|c|c|c|}
\hline Year & $\begin{array}{l}\text { Harmonized } \\
\text { System Group }\end{array}$ & $\begin{array}{c}\text { Harmonized } \\
\text { System Chapter }\end{array}$ & Description & $\%$ \\
\hline \multirow{5}{*}{1993} & Animal & 03 & $\begin{array}{l}\text { Fish and crustaceans, molluscs and } \\
\text { other aquatic invertebrates }\end{array}$ & 4,6 \\
\hline & Vegetable & 09 & Coffee, tea, mate and spices & 78,3 \\
\hline & Food Products & 21 & Miscellaneous edible preparations & 7,1 \\
\hline & Stone and Glass & 71 & $\begin{array}{l}\text { Natural, cultured pearls; precious, } \\
\text { semi-precious stones; others }\end{array}$ & 5,3 \\
\hline & & & Share & 95,4 \\
\hline \multirow{5}{*}{2003} & Vegetable & 09 & Coffee, tea, mate and spices & 13,5 \\
\hline & Food Products & 17 & Sugars and sugar confectionery & 0,6 \\
\hline & \multirow{2}{*}{ Metals } & 72 & Iron and steel & 79,7 \\
\hline & & 74 & Copper and articles thereof & 3,6 \\
\hline & & & Share & 97,3 \\
\hline \multirow{6}{*}{2013} & Vegetable & 09 & Coffee, tea, mate and spices & 20,7 \\
\hline & Fuels & 27 & $\begin{array}{l}\text { Mineral fuels, mineral oils and } \\
\text { products of their distillation; }(\ldots)\end{array}$ & 31,4 \\
\hline & \multirow{3}{*}{ Metals } & 72 & Iron and steel & 25,8 \\
\hline & & 74 & Copper and articles thereof & 5,0 \\
\hline & & 76 & Aluminium and articles thereof & 4,5 \\
\hline & & & Share & 87,4 \\
\hline
\end{tabular}

Source: Author elaboration based on UN Comtrade Database 
Appendix 5. Colombia's Main Imports from South Korea by Chapters

\begin{tabular}{|c|c|c|c|c|}
\hline Year & $\begin{array}{l}\text { Harmonized } \\
\text { System Group }\end{array}$ & $\begin{array}{c}\text { Harmonized } \\
\text { System Chapter }\end{array}$ & Description & $\%$ \\
\hline \multirow{6}{*}{1993} & \multirow{2}{*}{$\begin{array}{l}\text { Textiles and } \\
\text { Clothing }\end{array}$} & 54 & $\begin{array}{l}\text { Man-made filaments; strips and the } \\
\text { like of man-made textile materials }\end{array}$ & 5,1 \\
\hline & & 55 & Man-made staple fibres & 5,1 \\
\hline & \multirow{2}{*}{ Mach and Elec } & 84 & $\begin{array}{l}\text { Nuclear reactors, boilers, machinery } \\
\text { and mechanical appliances; (...) }\end{array}$ & 12,5 \\
\hline & & 85 & $\begin{array}{l}\text { Electrical machinery and equipment } \\
\text { and parts thereof: sound (...) }\end{array}$ & 22,0 \\
\hline & \multirow[t]{2}{*}{ Transportation } & 87 & $\begin{array}{l}\text { Vehicles; other than railway or } \\
\text { tramway rolling stock, (...) }\end{array}$ & 39,7 \\
\hline & & & Share & 84,4 \\
\hline \multirow{6}{*}{2003} & Plastic or Rubber & 39 & Plastics or articles thereof & 23,9 \\
\hline & $\begin{array}{l}\text { Textiles and } \\
\text { Clothing }\end{array}$ & 54 & $\begin{array}{l}\text { Man-made filaments; strips and the } \\
\text { like of man-made textile materials }\end{array}$ & 2,7 \\
\hline & \multirow{2}{*}{ Mach and Elec } & 84 & $\begin{array}{l}\text { Nuclear reactors, boilers, machinery } \\
\text { and mechanical appliances; (...) }\end{array}$ & 15,0 \\
\hline & & 85 & $\begin{array}{l}\text { Electrical machinery and equipment } \\
\text { and parts thereof: sound (...) }\end{array}$ & 23,1 \\
\hline & \multirow[t]{2}{*}{ Transportation } & 87 & $\begin{array}{l}\text { Vehicles; other than railway or } \\
\text { tramway rolling stock, }(\ldots)\end{array}$ & 17,6 \\
\hline & & & Share & 82,3 \\
\hline \multirow{7}{*}{2013} & \multirow{2}{*}{ Plastic or Rubber } & 39 & Plastics or articles thereof & 11,8 \\
\hline & & 40 & Rubber and articles thereof & 6,0 \\
\hline & Metals & 72 & Iron and steel & 5,2 \\
\hline & \multirow{2}{*}{ Mach and Elec } & 84 & $\begin{array}{l}\text { Nuclear reactors, boilers, machinery } \\
\text { and mechanical appliances; (...) }\end{array}$ & 14,3 \\
\hline & & 85 & $\begin{array}{l}\text { Electrical machinery and equipment } \\
\text { and parts thereof: sound (...) }\end{array}$ & 6,6 \\
\hline & \multirow[t]{2}{*}{ Transportation } & 87 & $\begin{array}{l}\text { Vehicles; other than railway or } \\
\text { tramway rolling stock, (...) }\end{array}$ & 41,5 \\
\hline & & & Share & 85,4 \\
\hline
\end{tabular}

Source: Author elaboration based on UN Comtrade Database 
Appendix 6. Definition of Variables and Data Sources

\begin{tabular}{|c|c|c|}
\hline Variable & Definition & Source \\
\hline Suscript $i$ & South Korea & \\
\hline Suscript $j$ & South Korea's trading partner & \\
\hline Suscript $t$ & Year of the period: $1993-2013$ & \\
\hline Xijt & Exports from $\mathrm{i}$ to $\mathrm{j}$ in year $\mathrm{t}$ (values in thousands of current dollars) & $\begin{array}{l}\text { World Integrated Trade } \\
\text { Solution (WITS) }\end{array}$ \\
\hline Mijt & Imports of country $\mathrm{i}$ from $\mathrm{j}$ in year $t$ & $\begin{array}{l}\text { World Integrated Trade } \\
\text { Solution (WITS) }\end{array}$ \\
\hline Yit & GDP of $\mathrm{i}$ in year $\mathrm{t}$ (values in thousands of current dollars) & World Bank \\
\hline Yjt & GDP of $\mathrm{j}$ in year $\mathrm{t}$ (values in thousands of current dollars) & World Bank \\
\hline Distij & $\begin{array}{l}\text { Geographical distance }(\mathrm{Km}) \text { between the } \\
\text { economic center of country i (Seoul, South Korea) } \\
\text { to the economic center of the country } j \text {. }\end{array}$ & CEPPI \\
\hline Leng_com & $\begin{array}{c}1=\text { if a language is spoken by at least } 9 \% \\
\text { of the population in both countries }\end{array}$ & CEPPI \\
\hline Colony & $1=$ if countries that have had colonial link & CEPPI \\
\hline Landlocked & $1=$ if $j$ is a landlocked country & CEPPI \\
\hline FTA & $1=$ if the countries have a free trade agreement & CEPPI \\
\hline$\mu_{i j}$ & Error term & WTO \\
\hline
\end{tabular}

Source: Author elaboration

Appendix 7. Woolridge Test for Autocorrelation in Panel Data

\begin{tabular}{cccc}
\hline Trade flow & Total & Primary & Industrial \\
\hline \multirow{2}{*}{ Exports } & $F(1,139)=9,688$ & $F(1,88)=17,903$ & $F(1,137)=9,405$ \\
& Prob $>F=0,0023$ & Prob $>F=0,001$ & Prob $>F=0,0026$ \\
Imports & $F(1,125)=81,896$ & $F(1,72)=75,599$ & $F(1,116)=65,657$ \\
& Prob $>F=0,0000$ & Prob $>F=0,0000$ & Prob $>F=0,0000$ \\
\hline
\end{tabular}

$\mathrm{HO}$ : no first-order autocorrelation

Source: Author elaboration 